Article

\title{
Becoming the Labyrinth: Negotiating Magical Space and Identity in Puella Magi Madoka Magica
}

\author{
Sara Cleto * and Erin Kathleen Bahl \\ Department of English, The Ohio State University, Columbus, OH 43210, USA; bahl.24@osu.edu \\ * Correspondence: cleto.2@osu.edu; Tel.: +1-404-808-8407 \\ Academic Editor: Claudia Schwabe \\ Received: 2 March 2016; Accepted: 30 March 2016; Published: 6 April 2016
}

\begin{abstract}
In the magical girl anime series Puella Magi Madoka Magica, middle-school girls receive the power and responsibility to fight witches in exchange for making a wish. The series has connections to many different genres and narrative traditions within the realm of folkloristics. However, the folkloric genre most relevant to the ethos and aesthetics of Madoka is that of the fairy tale. Drawing on Bill Ellis's concept of "fairy-telling" and scholarship on new media composition, in this paper we seek to investigate labyrinths as acts of embodied composing - not lairs of evil or destruction but rather creative material memory work that negotiates grief and despair. Many of the series' action sequences unfold in "labyrinths," the magical spaces controlled by witches. By composing a labyrinth, witches can simultaneously reshape their environment and create a powerful statement about identity through personalized performance in narrative spaces that they control. In particular, we argue that both the frameworks of "fairy tale" and "new media" give us useful analytical resources for beginning to make sense of the intricately complex phenomenon of Madoka's labyrinths.
\end{abstract}

Keywords: fairy tale; new media; anime; magical girl; labyrinth; Madoka

\section{Introduction}

In the anime series Puella Magi Madoka Magica [1] (hereafter Madoka), a granted wish marks not a happily-ever-after ending but rather a complicated beginning. In the first episode, middle-school girl Madoka Kaname meets a cat-like creature named Kyubey ${ }^{1}$ who offers to grant her and her friend Sayaka Miki any wish. In exchange, they must make contracts with him and become magical girls in order to fight witches, dangerous supernatural beings who spread curses and discord by mobilizing disruptive magical spaces called "labyrinths." As the storyline progresses, the girls discover that Kyubey was not transparent with them about the terms of their contracts. Although their wishes are indeed granted and they are given magical powers, magical girls eventually grow disillusioned with their task and succumb to despair, triggering their transformation into witches-meaning that in fighting the witches, they have really been fighting their own destinies all along.

Madoka has connections to many different genres and narrative traditions within the realm of folkloristics. The aesthetics of the labyrinth spaces draw upon the carnivalesque atmosphere of the festival, as do the performances that unfold within them. Figures drawn from historical legends, such as Joan of Arc and Cleopatra, appear in the final episodes of the series and are positioned on a continuum of magical girls, including the series' protagonists, throughout a reimagined history. Even myth is invoked as creation stories are explicitly unraveled and re-written at the series' conclusion. However, the folkloric genre most relevant to the ethos and aesthetics of Madoka is that of the fairy

1 Romanization of Japanese names is never entirely consistent across fan communities; sometimes multiple variations occur and are intensely debated. In this article, we use the versions as they are spelled in the officially released English subtitles. 
tale. Drawing on Bill Ellis's [2] concept of "fairy-telling" and scholarship on new media composition, we seek to investigate labyrinths as acts of embodied composing - not lairs of evil or destruction, but rather creative material memory work that negotiates grief and despair.

\section{The Anime}

The official Puella Magi Madoka Magica storyworld [3] is spread across several kinds of new media genres, including anime, manga, movies, and merchandise, along with numerous unofficial media formats such as fanfiction, fanart, and discussion forums. Our analysis will focus on the Madoka anime series, consisting of 12 episodes which originally aired in Japan in 2011 and were released in the U.S. via both online streaming and DVD in 2012 [4,5]. Over the course of the series, Madoka, who is reluctant to make a wish and become a magical girl, and Sayaka meet three girls who have already made contracts: Homura Akemi, Mami Tomoe, and Kyoko Sakura. Though they frequently clash with one another, they form uneasy alliances and battle witches together, but casualties are high. By the last two episodes, only Homura and Madoka remain, prompting Madoka to finally contract with Kyubey and become a magical girl with unique, unprecedented power.

Madoka not only features magical girls but is also an example of the "magical girl" genre of anime, which includes other series such as Sailor Moon, Cardcaptor Sakura, Prétear, and Princess Tutu. This series draws from many common elements of the genre, such as: middle-school-aged girls; an apparently average, somewhat inept heroine who reveals or receives magical powers; extended transformation scenes; and color-coded magical state costumes.However, Madoka also works within and against the magical girl genre, deliberately interrupting and subverting its conventions [6-8]. For example, Mami, the friendliest and most reliable of the magical girl characters, dies an unexpected and gruesome death during an early witch-battle, marking a distinct tonal shift in the series and shocking early audiences [9-11]. Additionally, the arrival of a small white catlike animal who possesses knowledge of magical powers and frequently appears in the main character's bedroom evokes the guardian-cats Luna and Artemis in the iconic magical girl anime Sailor Moon [12]. For the sailor scouts, these animal-like guardians serve as benevolent guides in helping the heroine discover and use her powers. However, Madoka and her friends eventually discover that Kyubey is part of an alien species that harvests the energy from magical girls' degeneration into witches in order to counteract the effects of cosmic entropy. These departures from genre convention draw attention to the question of narrative power: who can determine their own role within the narrative, and who can make their story stick? In a storyworld populated by bodies in flux and multiple timelines, the battle for narrative control and self-determination is paramount.

\section{The Labyrinth}

Many of the series' action sequences unfold in "labyrinths," magical spaces controlled by witches. Each witch possesses her own labyrinth, a disorienting maze both defensive and offensive- the labyrinth protects a witch's body from unexpected attacks, as a magical girl must survive and navigate the labyrinth before reaching the witch that resides at its center. It is a space in which the witch's will is externalized and made manifest, a personal, performative arena where combat between witch and magical girl takes place. The labyrinths themselves are highlighted by a marked shift in animation style-bold colors, collage-like layers, unusual textures, and erratic movements differentiate labyrinth sequences from the rest of the series, emphasizing their status as magical, otherworldly spaces with their own conventions and realities.

Despite the labyrinths' intensely personal nature, they are also public and confrontational. Although only magical girls can see witches, anyone can wander into a labyrinth, leaving them perpetually open to invasion and infiltration. Each labyrinth is composed of assorted objects and symbols, which vary depending on the personality of the witch that constructs it. In addition to the objects that fill the shifting paths of the labyrinths, each has at its center some kind of arena modeled after a public space. There are concert halls, formal gardens, and makeshift theatres-spaces 
in which communities traditionally come together for entertainment or celebrations. Labyrinths are personal and public, individual and yet reflective of community needs, echoing the material spectacle of festival ${ }^{2}$ in their composition and function.

While Madoka's labyrinths seem uniquely disruptive, they have precedence in other contemporary fairy-tale and new media narratives. Jim Henson's Labyrinth (1986) [13] and Guillermo del Toro's Pan's Labyrinth (2006) [14] both feature adolescent female heroines who encounter magical, morally questionable male figures as they pursue their labyrinthine quests. Although neither heroine is responsible for the physical construction of the labyrinth in her respective film, in both cases the young girls' wishes and imaginations play key roles in each labyrinth's creation, a connection that is strengthened in Madoka's witches' labyrinths.

In Madoka, the possession and construction of labyrinths is a highly gendered phenomenon. Magical girls and witches are exclusively female. Kyubey explains that his race has specifically targeted adolescent girls because they believe that this population experiences emotions more powerfully than any other demographic that they have encountered. Kyubey and his race exploit the magical girl's emotions and their descent into despair, harvesting the girls' expelled energy for the greater good.

This sharp, gendered demarcation is at odds with other aspects of the series, which seem to self-consciously counter rigid gender binaries. This is perhaps most explicit through the depictions of Madoka's parents. Her mother, Junko, is a high-powered business woman who expertly applies makeup, works late hours, and occasionally comes home drunk. Tomohisa, Madoka's father, appears to be a stay-at-home parent; he cooks, tends to the house and the garden, and fondly takes care of his wife when she is inebriated. Junko and Tomohisa appear to have a very happy marriage; Tomohisa even has an extended conversation with Madoka about how greatly he respects his wife and her choices, even when they appear to be eccentric or unconventional. These roles within the family are foregrounded in the first episode of the series, suggesting the desirability of more flexible gender roles even as the magical girls are forced into rigid identity narratives with predetermined destinies-and thus drawing those destinies into question.

Labyrinths, though still associated with a rigid gender binary (as only girls can create them), can offer another, more individualized form of meaning-making and self-determination. They are nonlinear and often highly disorienting because they are explicitly drawn from disjointed fragments and redeployed as a kind of personality assemblage. However disorienting these labyrinths may be, a complex cohesion underlies their chaotic appearances. In English, a "labyrinth" 3 is distinct from a "maze" insofar as the latter is a space of puzzlement offering multiple pathways, while the former, no matter how circuitous the route, ultimately leads to one destination ([17], p. 23; [18], p. 8). Additionally, in recent times, the practice of "walking the labyrinth" has gained popularity as a method of spiritual healing and self-integration in both secular and religious contexts [17,19-21]. Both perspectives shed light on how a labyrinth may be viewed as a powerful tool for creating internal cohesion amidst external confusion and disarray. By composing a labyrinth, witches can simultaneously reshape their environment and create a powerful statement about a complex, yet integrated identity through personalized performance in narrative spaces that they control. In particular, we argue that both the frameworks of "fairy tale" and "new media" give us useful analytical resources for beginning to make sense of the intricately complex phenomenon of Madoka's labyrinths.

\section{Fairy Tales}

"Fairy tale" is a contested term, and within fairy-tale studies definitions are frequently revised or redevised. Stith Thompson characterizes these stories as tales "involving a succession of motifs or

2 For further discussion of folklore and festival, see Noyes's Fire in the Plaça [15] and Foster's Pandemonium and Parade [16]. Our choice here to focus on the English word "labyrinth" as a translation for the original Japanese 結界, kekkai, is based on both the official English subtitled and dubbed anime episodes. 
episodes. [They move] in an unreal world without definite locality or definite creatures and [are] filled with the marvelous. In this never-never land, humble heroes kill adversaries, succeed to kingdoms and marry princesses" ([22], p. 8). More recently, scholars have emphasized the affordances of the fairy tale as a genre over its distinctive contents. Jennifer Schacker and Christine Jones suggest "that the idea of the fairy tale might be better understood as an open-ended, playful way of engaging social and political issues in a form that defies the constraints of realist fiction rather than as a fixed discursive form that corresponds to a set of narrative rules" ([23], p. 488). For the purposes of our exploration of fairy-tale space, the classic assessment from J.R.R. Tolkien is particularly apropos, as Tolkien grounds his definition in "the nature of Faërie: the Perilous Realm itself," a magical space in which the marvelous can unfold. For Tolkien, a fairy tale "touches on or uses Faerie, whatever its own main purpose may be: satire, adventure, morality, fantasy. Faerie itself may perhaps most nearly be translated by Magic - but it is magic of a peculiar mood and power" and "the magic itself...must...be taken seriously, neither laughed at nor explained away" ([24], p. 10). In Madoka "Faerie" finds a corollary within labyrinths, otherworldly spaces created and deployed by witches. In these magical realms, witches and girls battle for dominance, and magical identities are constructed and performed in ways that would be impossible in realistic or everyday space.

The influence of the Western fairy tale is pervasive within the genre of anime, as well as the related genre of manga. Fairy-tale characters and tropes are taken up and entextualized within new narratives, often with uncanny results as the familiar motifs become strange in their redeployment and ambiguity. Both the fairy tale and the narrative tradition of manga and anime "are ways of opening the participants' minds to the unknown, to asking questions about the way things are, and to tolerating the absence of conclusive answers" ([2], p. 21). The defamiliarization of these stories can result in innovative retellings and reconstructions. As Bill Ellis observes, "Western fairy tales often play an explicit part in these narratives in a form that is less influenced by Western cultural norms. For this reason, elements that are intrinsic to the genre of the fairy tale become more visible when we see how Japanese authors read and reinterpret these narratives, not as all-too-familiar stories but as exotic and novel ways of reimagining universal human dilemmas" ([2], pp. 21-22). Decoupled from the conventions that frequently govern them, these Western fairy-tale tropes can be redeployed to create revisions and new tales informed by the fairy-tale genre but distanced from generic expectations.

Furthermore, the genres of the fairy tale and anime complement each other thematically. Fantasy-based anime frequently emphasizes "the ubiquity of chaos and discord" in "labyrinthine" worlds populated by characters "beset by apparently insurmountable obstacles" ([25], p. 161). Yet, the fairy-tale dimension present in such series "serves to imbue the quest with a tenacious sense of hope. Through the contrast and conflation of a dystopian world and fairy-tale aesthetics, and even fairy-tale optimism, the anime accomplishes a synthesis of reality and fantasy of eerie and, at times, truly disquieting intensity" ([25], p. 161). While not all fairy tales feature happily-ever-after endings, their association with optimism and success persists, and this atmosphere of possibility, even positivity, can contribute much needed levity to those anime (such as Madoka) that feature apocalyptic landscapes.

\section{New Media}

Like "fairy tale," "new media" is a contested term with many possible definitions; in digital media studies, for example, "new media" composing blends into discussions of "multimodal," "multimedia," and "digital" composing [26-28]. In this study, we rely on Wysocki's definition of new media in order to focus on creative expressions that draw attention to (rather than efface) their materiality: for our purposes, "'new media texts' [are] those that have been made by composers who are aware of the range of materialities of texts and who then highlight the materiality...Under this definition, new media texts do not have to be digital; instead, any text that has been designed so that its materiality is not effaced can count as new media" ([29], p. 15). Expanding the concept of "new media" to emphasize materiality over digitality allows us to consider Madoka not only in terms of extradiegetic "new media," but also "new media" on the level of diegesis—-that is, how the characters within the story use the 
material resources around them to make meaning in a way that foregrounds the expressive media they use.

From the perspective of the magical girls in Madoka, the labyrinths are disorienting, confusing, non-linear, unintelligible, and perilous places-and therefore considered as unproductive and even evil. However, looking at these spaces through the lens of new media rhetoric and composing, we can see how those same ambiguous qualities also offer possibilities for interpretation as creative spaces of learning, discovery, and agential identity composing. For example, these labyrinths in many ways bear resemblances to a Wunderkammer (plural Wunderkammern), which Delagrange treats at length in her work on visual rhetoric, new media, and embodied composing [30,31]. Delagrange defines Wunderkammern as "cabinets or entire rooms in which naturally occurring and man-made artifacts were collected, collated and catalogued" ([31], "Revision"). As stages for arranging, displaying, and engaging curiosities of all kinds, a Wunderkammer serves as a space of both material and intellectual engagement; it is "an object-to-think-with that constructs an uncanny bridge between the mental and physical; it engenders wonder, a productive aporia between not-knowing and knowing" ([30], "Mental/Physical"). Likewise, a witch's labyrinth is a collection of objects meaningful to her life and identity in some way, carefully yet confusingly arranged and organized; it is an "uncanny" aporia, a space of puzzlement, both strange and familiar all at once ([32], p. 8) that challenges the ordinary sense-making strategies of those who try to navigate it.

As an "object-to-think-with," a labyrinth might additionally be viewed as rhetorical memory-making work enacted via new media objects. Turkle's collection Evocative Objects engages objects as "active life presences" with the power to "catalyze self-creation" ([32], p. 9), simultaneously "uncanny" and "rich with creative possibility" ([32], p. 8) in their ability to serve as identity-fashioning resources at key moments in an individual's development. Whittemore notes how the classical rhetorical technique of ars memoria employed imagined spaces as memory aids, whether walking through familiar spaces to remember talking points ("walking mnemonic") or observing scenery while sitting in the center of a theater ("memory theater") ([33], p. 6). It is interesting to note, as we will see in our case studies, that the witches' labyrinths foster both kinds of memory-making activities and spaces; the magical girls walk through half-familiar corridors in seeking out the witch, while the witch herself typically sits in the middle of a theater-like space at the center of the labyrinth. Like a Wunderkammer, Whittemore observes that these memory-spaces served as "both tools for learning and tools for finding," and comments that the most effective memory organization systems might not be file cabinets but rather "streetscapes and theaters" ([33], p. 6). These perspectives-uncanny spaces, evocative objects, memory-work, and learning through exploration-help us to reframe the witches' labyrinths not as evil spaces of absolute destruction, but as ambiguously, richly creative spaces for crafting identities and working through memories with the help of meaningful objects.

\section{New Media Fairy-Telling}

In analyzing Madoka's labyrinths as creative acts of new media composing, we borrow a term generated by Bill Ellis in his analysis of another magical girl anime (Princess Tutu). "Stretching our usual language," Ellis notes, "we could say that Princess Tutu is not about fairy tales at all but about fairy-telling, the ongoing tradition of generating new versions of old tales and inventing entirely new tales out of bits and pieces of existing ones" ([2], p. 231). Fairy-telling is both a critical and a creative act; one that involves "understanding the cultural grammar that governs fairy-telling and the gender conventions it makes visible, and gaining the skills to create new myths, ones that we can genuinely call our own" ([2], p. 236). In the witches' performances of memory-work-arranging "bits and pieces" of their lives, fairy tales, and the surrounding environment-their labyrinths become new tales, new interpretations of the world, the tellings of which are foregrounded in the hyper-materiality of their expression. In other words, the labyrinths can be viewed as acts of new media fairy-telling.

We apply these frameworks-fairy tale and new media together-to our close readings and analyses of three particularly significant witches' labyrinths that appear in Madoka: those of the 
witches Gertrud, Oktavia von Seckendorff, and Walpurgisnacht. Drawing from Ellis's definition of "fairy-telling" as the ongoing tradition of generating new versions of old tales and inventing entirely new tales out of bits and pieces of existing ones ([2], p. 231) and Wysocki's definition of new media composing as foregrounding a communicative act's materiality [29], we can look at the witches, in making their labyrinths, as powerful composers drawing on material objects from a fairy-tale repertoire and the stories of their lives in an act of creative embodied expression and identity-fashioning memory work.

\section{Case Study 1: Gertrud}

The first labyrinth to appear in the main timeline ${ }^{4}$ belongs to a witch named Gertrud. ${ }^{5}$ After an intimidating confrontation with their new classmate Homura, Madoka and Sayaka run from her and stumble into the labyrinth. They are disoriented and do not understand where they are or why their environment is changing so dramatically and rapidly. "Where did the exit go? Where are we?" Sayaka cries as gates and chains erupt into the concrete hallway through which they are running. The hallway quickly disappears behind an overlay of giant butterflies and windows floating unanchored in the air. In alignment with Sayaka's panicked question about the disappearance of the exit, this is a landscape that offers no avenue of escape-the chains and gates suggest entrapment and claustrophobia, and the windows are not only too high to reach but they are empty, revealing the landscape behind them instead of offering an exit into another space. As they try to make sense of their surroundings, with still more disconnected images flashing by, Madoka exclaims, "There's something wrong - the path keeps changing!" The name "labyrinth" is apt—like Wunderkammern, these are not spaces with clear trajectories, but rather dynamic, circuitous spaces that actively direct the traveler's movements rather than being passively moved through themselves.

In addition to more recognizable images and motifs including briars and roses-symbols intrinsic to many classic European fairy tales including Sleeping Beauty and Beauty and the Beast-there is a profusion of images that resist recognition or interpretation. Chief among these are animate cotton balls with thick black mustaches that laugh and dance over a garden bed, behind the roses and briars, and then dart unmoored across the screen before gathering around Madoka and Sayaka and chanting at them. The words of their chant are in untranslated German, unintended to render legible meaning for Japanese or English audiences. Even if the production company deliberately chose not to subtitle or dub the chanted words, in the midst of a capably, clearly dubbed series, the effect is of opaqueness and unintelligibility. As the chanting grows louder, the cotton-ball faces suddenly bare their teeth, and slashing scissors appear among the convulsing chains, heightening the threat of danger, and even dismemberment.

In the midst of this crescendo of sound and visual threat, the chains begin to break and fall to the ground, and a bright light surrounds the girls. From a newly made, clearly marked path, another magical girl, Mami, appears, holding her soul gem ${ }^{6}$, which emanates a bright, clear light, slicing through the chaos of the labyrinth and exerting creative control over its materials. As the girls greet each other, Gertrud's labyrinth, which has been subdued by Mami's appearance, begins to revive and thrash around the girls with renewed energy, reestablishing narrative dominance over her space. Mami promptly steps away from the other girls and engages her transformation sequence, in which her school uniform is replaced by her customized magical girl costume. At the end of her transformation,

4 Homura's magical girl powers include the capacity for time-travel, which she uses again and again in an attempt to save Madoka from death. Her actions create a succession of related timelines in the series. In this article, we have confined our discussion to the main timeline for the sake of clarity.

5 The name Gertrud does not appear in the 12-episode television series, but in the extended media associated with the Madoka world more broadly, she has been identified through the rune-like characters that appear in her labyrinth. We will refer to this witch as Gertrud for clarity.

6 A soul gem is the source of a magical girl's power. When it darkens from power loss or its owner's grief, a magical girl transforms into a witch. 
Mami stands on top of a large pile of Gertrud's accumulated objects, physically dominating the space. From this vantage point, she materializes a massive array of guns and fires them towards the heart of the labyrinth, forcing Gertrud to retreat, along with her labyrinth. The other-world of the labyrinth wavers and disappears, leaving the girls once more in the bare hallway in which the encounter began.

The next day, the girls encounter the same labyrinth — and this time, the witch herself as well. The witch has a head like a drooping rosebush, with a gelatinous body, butterfly wings, and roses scattered below her. As she and Mami battle, the witch ensnares her in a thick cord and dangles her high above her head. However, hyper-conscious of her role as a performer and her audience, Mami assures Madoka and Sayaka that she is fine, and laughs that "I can't let myself look uncool in front of my magical girl trainees." As the witch rushes at her, brandishing thorns and snapping scissors, golden ribbons rise from Mami's bulletholes and ensnare the witch in a tangle of yellow threads. While the witch struggles to free herself, Mami turns a swirling ribbon into an enormous gun and shoots her; the witch disappears in a swirl of golden light. Butterflies rise into the air as Mami drops to the ground with a bow, and the labyrinth evaporates around them. As Gertrud collapses, Mami punctuates her performance by materializing a cup of tea and calmly sipping from it. In defeating the witch, Mami literally takes her place at the center of the stage; her power to shape the story has prevailed, and the world crafted by the witch dissolves into nothingness.

The composition of Gertrud's labyrinth, despite its seeming chaos, draws heavily upon fairy-tale motifs from Beauty and the Beast (ATU 425), Rapunzel (ATU 310), and most particularly Sleeping Beauty $^{7}$ (ATU 410) [35]. Roses and gardening paraphernalia abound; the flowers and their briars appear again and again, in addition to the sinister cotton-plant faces, abundant butterflies, flowers, and tilled garden rows, and Gertrud's appearance as a vaguely humanoid rose bush with butterfly wings in her garden-arena heightens this impression. The cotton balls heighten a connection to Sleeping Beauty tales, as they are materials associated with spinning and spinning wheels. Furthermore, imagery of restraint and enclosure echo the iconic briars that surround Sleeping Beauty's castle in many famous versions of the tale [36,37]; the flowers and other garden objects are frequently crossed or intermingled with actual briars, along with chains, gates, and other obstructions. Gertrud decontextualizes and recombines these elements to mobilize her attacks on the magical girls that enter her domain, wielding roses and butterflies against Mami's guns in an act of creative fairy-telling.

Despite these gestures at meaning-making, Gertrud and her chosen objects are fundamentally opaque to her audiences - both the magical girls and the viewers of the anime. Gertrud's labyrinth is particularly resistant to interpretation because no information is provided about the witch that constructed it, the magical girl that she once was, or how these objects relate to her own narrative. While the other two case studies we examine in this article are discussed explicitly among characters within the diegetic world, Gertrud's space is an enigma that surfaces without warning, explanation, or backstory. The magical girls' reactions-their disgust with Gertrud's reimagined body and their confusion in the face of her labyrinth—are foregrounded, and so the anime's audience experiences disorientation with them. However, as the series progresses, context and backstory provide clues to reading a labyrinth, as well as insight into the personalities and the creativity that construct them.

\section{Case Study 2: Oktavia}

Because Sayaka's storyline gradually unfolds over the course of the series, the audience is able to interpret her labyrinth as a witch in the context of her memories and the symbols meaningful to her. The labyrinths are too complex to afford a one-to-one correlation between symbol and interpretation; their objects' richness lies in their ambiguity and ability to evoke rather than signify absolutely. Instead,

7 For further discussion of Sleeping Beauty in Japan, see Jorgensen and Warman's "Molding Messages: Analyzing the Reworking of 'Sleeping Beauty' in Grimm's Fairy Tale Classics and Dollhouse" [34]. 
we suggest that awareness of her personality and backstory allow a degree of transparency that was not accessible for Gertrud or the other witches that precede Sayaka's transformation.

When Kyoko finds her, Sayaka sits alone on a bench in a darkened train station. After an accelerating disenchantment with her magical girlhood and increasing dissatisfaction with her personal life, Sakaya is overcome by despair and transforms from a magical girl to a witch. As Kyoko looks on in horror, Sayaka's physical body falls into the emergent labyrinth, and the train station transforms into an ocean scene, crossed with trains, tracks, and flying wheels, and punctuated with staves and music notes. At the center of this chaos is a witch, identified by flashing rune-like letters as Oktavia von Seckendorff. The looming figure wears a dark blue cloak reminiscent of Sayaka's blue magical girl cape, with a pink bow, ornate ruff, and loudspeaker-like helmet; she has a brightly colored mermaid tail and is seated upon an array of knightly pennants. The remaining magical girls take Sayaka's vacant human body and flee the labyrinth, unwilling to harm their friend in her witch form.

In an attempt to save Sayaka, Kyoko and Madoka reenter her labyrinth, which first appears as a quiet brick hallway lined with rune-scripted concert posters. Deeper in, the next hallway is more ornate, with red-carpeted floors, gold-adorned pillars, and round glass screens playing hazy images from Sayaka's memories. Suddenly, the doors snap shut behind them; the screens go black, and Kyoko warns, "She knows we're here! She's coming!" As with Gertrud's labyrinth, the witch's approach is signaled not by any motion on the part of the magical girls, but rather by the entire labyrinth rushing toward them as a series of doors opening up into a spacious concert hall, emphasizing the collapse of distinction between witch and labyrinth, narrative and performance. The hall is lined from floor to ceiling with red seats; off to one side, the silhouette of a conductor directs an orchestra-completely comprised of violinists-with inexorable regularity. At the center of the hall is Oktavia, swaying from side to side in time with the orchestra, sword raised like a baton. The train imagery returns when the girls approach her; as the witch raises her sword, spinning train wheels (both metallic and musical) appear and loom threateningly above Kyoko and Madoka. Madoka is protected by Kyoko's barrier, but the witch circles around the hall, hurling wheels at the magical girl. Although the witch carries a sword, she uses it to direct the wheels rather than to fight with the blade; her will is equally materialized through her body and her assembled labyrinth.

In viewing the labyrinth as an act of creative expression, as a material network through which the witch's identity is distributed, Oktavia composes her labyrinth from elements clearly related to her own memories. The train imagery, for example, evokes a key location from her transition to despair; it was a conversation she overheard on a train that made her question and ultimately reject her fight to protect humanity. In particular, music plays a key role in relation to Kyosuke, the boy she loves. Sayaka becomes a magical girl to help him; her wish is for his hand to be healed after an injury so that he could play violin again. However, as in life, she remains on the edge of the music; in her labyrinth, she places herself in an ambiguous role between conductor and audience. Although she clearly orchestrates the entire scene, at the same time she is removed from the orchestra and even the conductor figurehead, a listener rather than a musician herself. The labyrinth expresses an active power over music that she never possessed in life; even without a violin in hand, the performance is still very much her own.

Because two separate incarnations of Oktavia's labyrinth are depicted in the series, they can be understood as two iterations of the same narrative act. The same elements, particularly train tracks, wheels, and music notes, are drawn from the witch's memory and recast across different landscapes within the labyrinth. In this sense, the witch's creation/performance of each labyrinth echoes the tension between continuity and change that govern the (re)telling of a fairy tale, during which some elements remain consistent while others adapt based on changing factors like audience, context, and locale ([2], p. 233). The elements that Oktavia uses to construct her labyrinth are drawn from her memories as well as from fairy-tale tropes, and she remixes these pieces to create multiple versions of her own memory-narrative.

Between the oceanic theme that resurfaces across different incarnations of the labyrinth, Oktavia's mermaid tail, bodies in flux, unrequited love, and an emphasis on music, the fairy tale of "The 
Little Mermaid" serves as a useful intertext for decoding this labyrinth. Written by Hans Christian Andersen [38], and further popularized by Disney with their cinematic retelling [39], the fairy tale has been recently revitalized in Japan with Hayao Miyazaki's film adaptation Ponyo [40]. The motifs from the fairy tale resurface disjointedly, echoing across Oktavia's body and the labyrinthine landscape. Her memories of the boy are given shape by figures within the labyrinth as well as the orchestra comprised only of his chosen instrument. Within her labyrinth, Oktavia uses the affordances of new media fairy-telling to reimagine the boy she loves and to recast their relationship through the material fragments of a familiar tale. In this way, remembrance and creative storytelling intersect to frame a space in which Oktavia can grieve and reestablish narrative control over her story.

\section{Case Study 3: Walpurgisnacht}

The final labyrinth we wish to examine is that of the witch Walpurgisnacht ${ }^{8}$, the crucial point around which the entire series has circled. The series actually begins with an encounter with Walpurgisnacht, although only her silhouette and the pieces of her labyrinth are pictured without any explanation. It is not until episode ten, when the multiple timelines are revealed and the same images are repeated, that the audience recognizes Walpurgisnacht and realizes the extent to which her presence has shaped the narrative and the vast scope of her compositional power. Unlike the other labyrinths encountered thus far, the witch Walpurgisnacht does not simply incorporate pieces of the "real world" into the creation of her magical labyrinth space. Rather, she is so powerful as to project her labyrinth over the entire city, blurring the lines between real and magical worlds beyond distinction.

Because Walpurgisnacht's labyrinth interrupts the structural integrity of the real world, the city's inhabitants perceive her appearance as a series of natural disasters and retreat to evacuation shelters. Homura, the last surviving magical girl, stands alone looking out over the empty streets. Following a festival procession of fantastic creatures, lacy curtains part and ornate numbers count down from five to one, heightening the anticipation of a spectacle just about to begin. In many ways, though, the spectacle has long been underway; the same lacy curtains, which resemble Walpurgisnacht's skirt, opens the Madoka series at the beginning of the very first episode, implying that the direction of the narrative has been under Walpurgisnacht's control all along.

Like Gertrud, Oktavia, and the other witches, Walpurgisnacht's body is composite. She has the most humanoid body-rather than mobilizing rosebushes or animal bodies to mimic a human form, Walpurgisnacht has the appearance of a woman. She wears an elaborate, blue gown with exaggerated bell sleeves and a cascading, tiered skirt. On her head sits a formal headdress reminiscent of medieval European nobility; it tapers to two sharp points, suggesting horns or a crown. Her face possesses prominent red lips and teeth but no other discernible features. Her back and limbs are long and straight, suggesting a regal bearing. She resembles nothing so much as an evil queen, a figure popularized most by Snow White tales (ATU 709) [35], particularly the Grimms' version [30]. Appropriately, Snow White focuses on intergenerational conflicts between women, which might be mapped onto the struggle between the youthful magical girls and the more experienced witches. Walpurgisnacht's headdress and queenly, but monstrous, appearance also suggests a connection to the villain of another iconic sleeping maiden fairy tale, Sleeping Beauty—particularly her incarnations in Disney's films Sleeping Beauty (1959) [41] and Maleficent (2014) [42] (though the latter was released several years after Madoka aired). In these versions, the witch-like fairy wears a headdress with two sharp, prominent points shaped to resemble horns-and in Maleficent, she is revealed to actually possess horns, which the headdress later envelops. Walpugisnacht's resemblance to magically powerful, morally questionable fairy-tale queens establishes the scope of her ability, and imbues the stakes of the magical girls' fight against the witch with fairy-tale wonder and weight.

8 In Germanic folklore, "Walpurgisnacht" is a night for a witches' gathering. 
Despite her resemblance to these familiar fairy-tale figures, Walpurgisnacht's appearance is uniquely uncanny. Her torso rests not on legs but on a giant stack of gears that fits beneath her skirts. She hovers above the cityscape, her humanoid body inverted, her head tilted towards the ground. She occasionally emits eerie, high-pitched laughter, particularly when Homura attacks her with an incredible barrage of explosives. Half humanoid, half machine, Walpurgisnacht utilizes fairy-telling fragmentation to assemble a body and labyrinth that speak to multiple discourses of material and narrative power. Walpurgisnacht is by far the most powerful witch yet encountered in the series: instead of hiding within a labyrinth, she projects her will and personality onto the world around her, dovetailing with the fairy-tale motifs of feminine power that she has reappropriated. While the preceding witches in the series challenged the demarcations between body and labyrinthine materials, reality and labyrinth-space, Walpurgisnacht shatters the boundaries as she imposes her physical body and her mental desires into and onto everyday reality. Her resemblance to recognizable fairy-tale witches/fairies heightens the perception of her ability to interrupt orderly hierarchies and to threaten established discourses of meaning-making through her power to re-compose the world into her own labyrinth.

\section{Discussion: Composing and Telling}

The power to compose the world ultimately does not belong to Walpurgisnacht, however, but to Madoka. In order to save Homura from an endless cycle of irresolvable conflict, and all magical girls from becoming witches, she makes a wish to literally rewrite the laws of the universe: to erase all witches before they are born by taking all magical girls' despair upon herself-and thus erasing herself from the normal plane of existence altogether as she is undone by her own wish. We see the effect of her wish in undoing Walpurgisnacht; as the laughing witch floats through the city, debris still strewn across the skies and Madoka's pink arrows raining down around her, she starts to disintegrate piece by piece until only her gear half remains. By the time Homura returns to the "present" timeline, the witch's presence has been entirely erased.

From the angles of fairy-telling and new media composing, we can start to see the witches and their labyrinths in a new light. The witches are clearly dangerous, with the potential for considerable destruction-yet at their core they are not evil monsters, but rather grieving young women. Instead of insidious lairs, we might look at the labyrinths as creative attempts at healing, sense-making, and identity-fashioning in the midst of despair. This is not a passive despair, a helpless grief. It has a life, power, and vitality of its own, taking pieces of memory and rearranging them in combination with fairy tales and everyday objects-a grief that has given up so thoroughly on the old world that it creates a new one instead out of the shards and sparks of mourning. For the witches, their role in Kyubey's plans are complete; once they have completed the transformation, Kyubey has no further need for them, apart from serving as enemies for future magical girls, and they are narratively free to compose their own stories via their labyrinths without any apparent need of any further sustenance apart from their own powers.

Herein lies the paradox. Madoka wants to save magical girls from despair and hatred; however, following her universe-shattering wish, when magical girls exhaust their power or fall into despair there is still no hope of healing. They are simply erased, body and soul, as Mami explains: "Before the hope we wished for summons an equivalent amount of misfortune, we have no choice but to vanish from this world." As witches, the girls had power, creativity, individual expression, and embodiment in the midst of their despair, the power to shape the world around them with their assembled story-worlds; with Madoka's new system, however, even that ambiguous power and creativity is denied them, and they are literally wiped out of existence. In taking the magical girls' despair upon herself, Madoka has not saved them; she has trapped them further by ensuring their complete erasure the moment hope or magic fails, and sapping all creative embodied power from their grief. The cycle continues, there is no redemption, and the curses have merely taken a different form-what has been lost, though, are the power, material bodies, and individual creativity of the witches who were once magical girls. 
We do not suggest that the witches are unambiguously good-after all, their labyrinths are extremely destructive intrusions into the real-world cityscape, and the curses that they spread result in contagious despair and even death for those who encounter them. But we do wish to foreground the creative potential of their labyrinths, as well as the narrative possibilities that they can present.

Madoka's vision of a better world takes away the witches' feelings of despair, but erases the magical girls entirely in the process. Rather than saving them, she leaves them with even less agency; their ability to feel and exist is taken away altogether. We might use Cornell's three minimum qualifications of individuation, as applied by Fleckenstein ([43], pp. 243-44) to new media composing, in order to critique this ending. A legal ethicist, Cornell posits that laws working towards greatest agency for all individuals involved (especially women) must meet at least three criteria: bodily integrity; access to symbol systems; and protection of the imaginary domain, which she defines as "the space of the 'as if' in which we imagine who we might be if we made ourselves our own end and claimed ourselves as our own person" ([43], quoted p. 244). Madoka's new universe fails these three criteria through the complete erasure of magical girl subjects. Conversely, even in their despair, the witches maintain bodily integrity through continued physical existence (and even an expanded existence, in considering the labyrinths as extensions of themselves); they have rich symbolic access to "develop and explore a robust matrix of personae" in the act of "renarrating and resymbolizing" themselves ([43], p. 244); and they are able to inhabit a space of self-reimagining and refashioning within their labyrinths as protected imaginary domains. For all their other complicated resonances, from this perspective the labyrinths can be seen as—uncanny, disorienting, sinister, but also liberatory-spaces of fairy-telling and new media composing.

\section{Conclusions}

Just as Madoka deliberately subverts the magical girl genre, so might it also deliberately encourage us to read against the grain of its own ending - to be a magical girl, without the ability to experience the full range of human emotions, good and bad, may be temporarily empowering but ultimately leads to the total erasure of the self, both body and soul. Ellis notes that in Japanese fairy tales, powerful women were frequently portrayed as monsters such as mountain ogres-kin, in a sense, to the witches and evil queens of Western fairy tales ([2], p. 222). In this light, perhaps the ultimate evil is not to become a witch - grieving and beyond the bounds of normal human society, but still embodied and powerful—but rather to be a magical girl—destined for complete erasure once her magic runs out. Donna Haraway claims that it is better to be a cyborg than a goddess ([44], p. 46); in the end, perhaps it is better to become a labyrinth rather than disappear as a magical girl.

Author Contributions: Sara Cleto and Erin Bahl developed concepts, researched secondary materials, and wrote the article in equal parts. Sara Cleto contributed the sections on fairy tales, while Erin Bahl contributed the sections on new media, but the article was a collaborative process.

Conflicts of Interest: The authors declare no conflict of interest.

\section{Abbreviations}

Madoka Refers to the anime series Puella Magi Madoka Magica

\section{References}

1. Puella Magi Madoka Magica. Directed by Akiyuki Shinbo. Tokyo: Prod. Shaft and Aniplex, 2011.

2. Bill Ellis. "The Fairy-telling Craft of Princess Tutu: Metacommentary and the Folkloresque." In The Folkloresque: Reframing Folklore in a Popular Culture World. Edited by Michael Dylan Foster and Jeffrey A. Tolbert. Logan: Utah State University Press, 2016, pp. 221-40.

3. Marie-Laure Ryan, and Jan-Noël Thon. Storyworlds across Media: Toward a Media-Conscious Narratology. Lincoln: University of Nebraska Press, 2014. 
4. Anime News Network. "Crackle, Hulu Also Stream Puella Magi Madoka Magica Anime." Anime News Network, 15 February 2012. Available online: http://www.animenewsnetwork.com/news/2012-02-15/ crackle-hulu-also-stream-puella-magi-madoka-magica-anime (accessed on 6 February 2016).

5. Anime News Network. "Madoka Magica to Get English BDs Starting February 14 (Updated)." Anime News Network, 14 October 2011. Available online: http:/ /www.animenewsnetwork.com/news/2011-10-14/ madoka-magica-to-get-english-bds-starting-february-14 (accessed on 6 February 2016).

6. Did You Know Anime. "Puella Magi Madoka Magica-Did You Know Anime? Feat. Kinenz." YouTube, 7 May 2015. Available online: https://www.youtube.com/watch?v=9ArGWxjYCnA (accessed on 6 February 2016).

7. Liz Ohanesian. "How Puella Magi Madoka Magica Shatters Anime Stereotypes." LA Weekly.com, 22 October 2012. Available online: http://www.laweekly.com/arts/how-puella-magi-madoka-magicashatters-anime-stereotypes-2373077 (accessed on 6 February 2016).

8. Erinn Velez. "Breaking the Mold: Puella Magi Madoka Magica Flips the Magical Girl Genre On Its Ear." PopCults.com, 9 March 2013. Available online: http://www.popcults.com/puella-magi-madoka-magicaanime-review/ (accessed on 6 February 2016).

9. Tsuyoshi Hariyoshi. "Various Reactions to Mami's Death in Madoka." YouTube, 18 July 2011. Available online: https:/ / www.youtube.com/watch?v=RJcJkstDReQ (accessed on 6 February 2016).

10. Panderarchive. "An Average Reaction to Madoka: Episode 3." YouTube, 12 February 2013. Available online: https:/ / www.youtube.com/watch?v=E5Fliy0kEQ8 (accessed on 6 February 2016).

11. Time Keeper. "Madoka Magica-Episode 3 Reaction Compilation." YouTube, 26 July 2015. Available online: https://www.youtube.com/watch?v=AYIgv5OP9X0 (accessed on 6 February 2016).

12. Pretty Soldier Sailor Moon. Directed by Junichi Sato. Tokyo: Toei Animation, 1992-1993.

13. Labyrinth. Directed by Jim Henson. Dayton: Henson Associates, Inc. and Lucasfilm Ltd., 1986.

14. Pan's Labyrinth. Directed by Guillermo del Toro. Sherman Oaks: Esperanto Films, 2006.

15. Dorothy Noyes. Fire in the Plaça: Catalan Festival Politics after Franco. Philadelphia: University of Pennsylvania Press, 2003.

16. Michael Dylan Foster. Pandemonium and Parade: Japanese Monsters and the Culture of Yokai. Berkeley: University of California Press, 2008.

17. Vanessa Compton. "Labyrinths in the Landscape: A Primer." Landscapes/Paysages 16 (2014): $23-25$.

18. Jeff Saward. Magical Paths: Labyrinths and Mazes in the 21st Century. London: Mitchell Beazley, 2002.

19. Maddy Cunningham. Integrating Spirituality in Clinical Social Work Practice: Walking the Labyrinth. New York: Pearson Press, 2011.

20. Lizzie Hopthrow. "Labyrinth: Reclaiming an ancient spiritual tool for a modern healthcare setting." Journal of Holistic Healthcare 10 (2013): 38-41.

21. Sally Welch. Walking the Labyrinth: A Spiritual and Practical Guide. London: Canterbury Press, 2010.

22. Stith Thompson. The Folktale. Berkeley: University of California Press, 1977.

23. Jennifer Schacker, and Christine Jones. "Introduction: How to read the critical essays." In Marvelous Transformations: An Anthology of Fairy Tales and Contemporary Critical Perspectives. Edited by Jennifer Schacker and Christine Jones. New York: Broadview Press, 2013, pp. 485-92.

24. John Ronald Reuel Tolkien. “On Fairy Stories.” In The Tolkien Reader. New York: Ballantine Books, 1966, pp. 3-84.

25. Dani Cavallaro. The Fairy Tale and Anime: Traditional Themes, Images and Symbols at Play on Screen. London: McFarland \& Company, Inc., 2011.

26. Claire Lauer. "What's in a name? The Anatomy of Defining New/Multi/Modal/Digital/Media Texts." Kairos: A Journal of Rhetoric, Technology, and Pedagogy, 2012. Available online: http://kairos.techn orhetoric.net/17.1/ (accessed on 20 February 2016).

27. Lev Manovich. The Language of New Media. Cambridge: Massachussetts Institute of Technology, 2001.

28. Jody Shipka. Toward a Composition Made Whole. Pittsburgh: University of Pittsburgh Press, 2011.

29. Anne Frances Wysocki. "Opening New Media to Writing: Openings and Justifications." In Writing New Media: Theory and Applications for Expanding the Teaching of Composition. Edited by Anne Frances Wysocki, Johndan Johnson-Eilola, Cynthia L. Selfe and Geoffrey Sirc. Logan: Utah State University Press, 2004, pp. 1-42. 
30. Susan Delagrange. "Wunderkammer, Cornell, and the Visual Canon of Arrangement." Kairos: A Journal of Rhetoric, Technology, and Pedagogy, 2009. Available online: http://kairos.technorhetoric.net/13.2/topoi/ delagrange/ (accessed on 20 February 2016).

31. Susan Delagrange. "When Revision is Redesign: Key Questions for Digital Scholarship." Kairos: A Journal of Rhetoric, Technology, and Pedagogy, 2009. Available online: http://kairos.technorhetoric.net/ 14.1/inventio/delagrange/ (accessed on 20 February 2016).

32. Sherry Turkle. "Introduction: The Things That Matter." In Evocative Objects: Things We Think With. Edited by Sherry Turkle. Cambridge: Massachusetts Institute of Technology, 2007, pp. 3-10.

33. Stewart Whittemore. "Finding and learning: Exploring the information management practices of a technical communicator." Paper presented at IEEE International Professional Communication Conference, Waikiki, HI, USA, 19-22 July 2009, pp. 1-7. Available online: http:/ /ieeexplore.ieee.org/xpl/articleDetails. jsp?arnumber $=5208677$ (accessed on 20 February 2016).

34. Jeana Jorgensen, and Brittany Warman. "Molding Messages: Analyzing the Reworking of 'Sleeping Beauty' in Grimm's Fairy Tale Classics and Dollhouse." In Channeling Wonder: Fairy Tales on Television. Edited by Pauline Greenhill and Jill Terry Rudy. Detroit: Wayne State University Press, 2014, pp. 144-62.

35. Antti Arne, Stith Thompson, and Hans-Jörg Uther. The Types of International Folktales. A Classification and Bibliography. Helsinki: Finnish Academy of Science and Letters, 2011.

36. Charles Perrault. The Complete Fairy Tales in Verse and Prose. Translated by Stanley Appelbaum Mineola. New York: Dover Publications, 2002.

37. Jakob Grimm, and Wilhelm Grimm. Children's and Household Tales. Edited by Ken Mondschein. San Diego: Canterbury Classics, 2011.

38. Hans Christian Andersen. The Complete Fairy Tales and Stories. Translated by Erik Christian Haugaard. New York: Random House, 1983.

39. The Little Mermaid. Directed by Ron Clements and John Musker. Burbank: Walt Disney Pictures, 1989.

40. Ponyo. Directed by Hayao Miyazaki. Tokyo: Studio Ghibli, 2008.

41. Sleeping Beauty. Directed by Clyde Geronimi. Burbank: Disney, 1959.

42. Maleficent. Directed by Robert Stromberg. Burbank: Disney, 2014.

43. Kristie Fleckenstein. "Affording New Media: Individuation, Imagination, and the Hope of Change." In Composing (Media)=Composing (Embodiment): Bodies, Technologies, Writing, the Teaching of Writing. Edited by Kristin L. Arola and Anne Frances Wysocki. Boulder: University of Boulder Press, 2012, pp. 239-58.

44. Donna Haraway. "A Manifesto for Cyborgs: Science, Technology, and Socialist Feminism in the 1980s." In The Donna Haraway Reader. New York: Routledge, 2004, pp. 7-46. 